\title{
Processing Map and Hot Deformation Behavior of Mo-Nb Single Crystals
}

\author{
Zhang Wen ${ }^{1,2}$, Gao Xuanqiao², Cheng Jun², Hu Zhongwu ${ }^{2}$, Li Laiping ${ }^{2}$, \\ Zhao Bin $^{1,2}$, Zhang Pingxiang ${ }^{1,2}$ \\ ${ }^{1}$ Northwestern Polytechnical University, Xi'an 710072, China; ${ }^{2}$ Northwest Institute for Nonferrous Metal Research, Xi'an 710016, China
}

\begin{abstract}
The processing map of Mo-Nb single crystals was established on the base of Prasad instability. The hot deformation behavior of Mo-Nb single crystals has been characterized through stress-strain curves and processing map in the temperature range of $1100 \sim 1300{ }^{\circ} \mathrm{C}$ and strain rate range of $0.001 \sim 10 \mathrm{~s}^{-1}$. The results indicate that the flow stress is affected significantly by deformation temperature and strain rate during the hot deformation of Mo-Nb single crystals. Based on the processing map, the optimum condition for hot deformation of Mo-Nb single crystals is in the region of high temperatures $\left(>1190^{\circ} \mathrm{C}\right)$ and high strain rates $\left(>3.16 \mathrm{~s}^{-1}\right)$. Microstructure observation of deformed specimens at different deforming conditions shows that lots of orthogonal cracks, which result from the movement of dislocations along with the glide planes, are observed in specimens deformed at 1100 ${ }^{\circ} \mathrm{C} / 0.01 \mathrm{~s}^{-1}$ and $1150{ }^{\circ} \mathrm{C} / 10 \mathrm{~s}^{-1}$. Less cracks can be observed in specimens deformed at $1250{ }^{\circ} \mathrm{C} / 0.01 \mathrm{~s}^{-1}$, and few cracks are found in specimens deformed at $1300{ }^{\circ} \mathrm{C} / 10 \mathrm{~s}^{-1}$. The XRD result shows that the specimen deformed at $1300{ }^{\circ} \mathrm{C} / 10 \mathrm{~s}^{-1}$ retains single crystal structure, indicating that the specimen does not undergo instability of flow during hot deformation, which are in good agreement with the results of Mo-Nb single crystals predicted from processing map.
\end{abstract}

Key words: Mo-Nb single crystals; processing map; isothermal compression

Many components in the advanced energy systems are required to resist high temperature and serve without significant deformation over long term application. For instance, the resistance of high temperature $(2000 \mathrm{~K})$ over lifetimes of over ten years is one of the necessary premises for fuel elements used in thermionic systems ${ }^{[1]}$. Only molybdenum and tungsten and their alloys can withstand the extreme application condition. Due to the absence of grain boundaries and the presence of strengthening solutes, single crystalline alloys have excellent high temperature strength and microstructure stability in the class of materials. Compared to polycrystalline counterparts, single crystalline molybdenum and tungsten have a series of advantages, such as the high strength, appropriate plasticity, high Young's modulus, stable microstructures, low creep rates, low diffusion penetrability, excellent wear resistance and compatibility with nuclear fuels, which make molybdenum and tungsten single crystals suitable for applications in various high technology fields, including linear accelerators and colliders ${ }^{[2]}$. Furthermore, oriented single crystalline tungsten and molybdenum are suitable for manufacture of the emitter for advanced energy systems in space reactor $^{[3,4]}$.

Molybdenum single crystals have many advantages over polycrystalline alloys ${ }^{[5]}$. Atomic size mismatch and alloy content have significant effects on creep rates, and niobium were considered as the best strengthening agents due to their large atomic size mismatch and high solubility ${ }^{[6]}$. But the application of Mo-Nb single crystals is very limited at present, only used as the emitter of advanced space equipment power supply system at present ${ }^{[7]}$. The Mo-Nb single crystals as emitter do not need to be deformed during the production. In fact, the high temperature steady state creep rates of the Mo-Nb single crystals are more concerned by researchers ${ }^{[8,9]}$. But researchers still don't know much about the hot

$\overline{\text { Received date: April 25, } 2017}$

Corresponding author: Zhang Wen, Candidate for Ph. D., Senior Engineer, Northwestern Polytechnical University, Xi'an 710072, P. R. China, Tel: 0086-29-86231082, E-mail: gwenzh@163.com 
deformation behavior of this materials. Some literatures are mainly focused on the preparation process, especially works using processing maps to study the relationship between flow stress and deformation characteristics for Mo- $\mathrm{Nb}$ single crystals undergoing thermal deformation have rarely been reported. The present work focuses on deformation behavior of Mo-Nb single crystals through strain-stress curves and processing map, and the purpose is to understand the effect of hot compression conditions on its microstructure. This work is an exploration to acquire the appropriate deformation conditions for this material. It means that if the material can still retain a single crystal structure without any macro or micro defects under some deformation conditions, then the possibility of other applications will be discussed.

\section{Experiment}

The high purity Mo-Nb single crystals rod was provided by Northwest Institute for Nonferrous Metal Research, growing in the electron-beam floating zone melting furnace ${ }^{[10]}$. The chemical composition of Mo-Nb single crystals is given in Table 1 and the microstructure of specimen is shown in Fig.1.

The specimens were cut out from the Mo-Nb single crystals rod with diameter of $28 \mathrm{~mm}$ along the longitudinal-axis; afterwards they were machined into $8 \mathrm{~mm}$ in diameter and 12 $\mathrm{mm}$ in height for the hot compression tests. A series of thermal compression tests were conducted on Gleeble-3800 thermal simulator to collect thermal deformation data in the deformation temperature range from $1100{ }^{\circ} \mathrm{C}$ to $1300{ }^{\circ} \mathrm{C}$ and strain rate range from $0.001 \mathrm{~s}^{-1}$ to $10 \mathrm{~s}^{-1}$. The specimens were deformed up to $50 \%$, and quenched to room temperature in order to preserve the microstructures for the microstructural study of deformed profiles. After deformation, the deformed specimens were cut along the compression axis and the longitudinal sections were polished and etched in a solution $\left(\mathrm{HCl}+\mathrm{HNO}_{3}\right)$ at room temperature. The microstructures of deformed Mo-Nb single crystals

Table 1 Chemical composition of Mo-Nb single crystals

\begin{tabular}{|c|c|c|c|c|c|c|c|c|}
\hline Mo & $\mathrm{Nb}$ & $\mathrm{C}$ & $\mathrm{N}$ & $\mathrm{H}$ & $\mathrm{O}$ & $\mathrm{Fe}$ & $\mathrm{Si}$ & $\mathrm{Al}$ \\
\hline \multicolumn{2}{|c|}{ Content/wt $\%$} & \multicolumn{7}{|c|}{ Content $/ \mu \mathrm{g} \cdot \mathrm{g}^{-1}$} \\
\hline Bal. & 3.1 & $<50$ & $<30$ & $<10$ & $<30$ & $<1$ & $<1$ & $<1$ \\
\hline
\end{tabular}

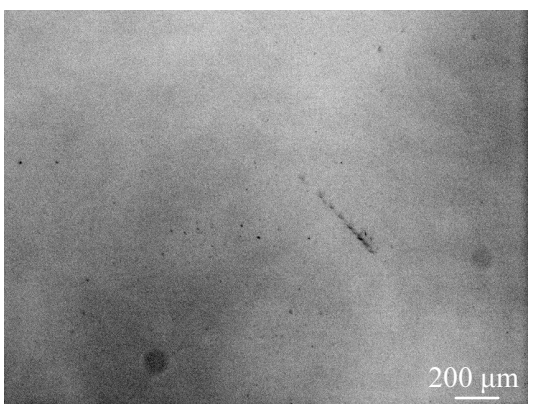

Fig.1 OM image of Mo-Nb single crystals were analyzed with Axio vert A1/Stemi2000 optical microscope and JSM-6460 scanning electron microscopy.

\section{Results and Discussion}

\subsection{Stress-strain curves}

The typical stress-strain curves obtained during thermal compression deformation of $\mathrm{Mo}-\mathrm{Nb}$ single crystals in the deformation temperature range of $1100 \sim 1300{ }^{\circ} \mathrm{C}$ and strain rate range of $0.001 \sim 10 \mathrm{~s}^{-1}$ are shown in Fig.2. As shown in Fig.2, the flow stress of Mo-Nb single crystals increases sharply with increasing of strain in the initial stage of thermal deformation due to the work hardening effect. The flow stress during the thermal deformation of $\mathrm{Mo}-\mathrm{Nb}$ single crystals is affected significantly by the deformation temperature and strain rate. The flow stress decreases with increasing of the deformation temperature, and increases with increasing of the strain rate. The true stress initially reaches to the peak stress and then decreases with the strain increasing gradually. In addition, it is worthy noting that the curves of Mo- $\mathrm{Nb}$ single crystals show a significant serrated oscillation for the strain rates of 1 and $10 \mathrm{~s}^{-1}$, which may suggest the effect of local warming, microstructural evolution and deformation instability are greater than that of the work hardening, and results in irregular change of true strain ${ }^{[11]}$. Plasticity of metal single crystals consists with the unique thermoplasticity and the transfer thermoplasticity. Thermoplastic weakens single crystal cohesion between atoms during heating, oscillation and diffusion movements of atoms increase, resulting in irregular decreasing of true stress ${ }^{[12]}$. Generally, the stress-strain curve articulates the intrinsic relationship between flow stress and thermodynamic behavior. However, during hot working, the flow curves may exhibit steady state, continuous softening or oscillation under different processing conditions. Thus it is quite difficult to determine the hot deformation mechanisms only relying on the shapes of the flow stress-strain curves, because several similar flow behaviors may result in different microstructural mechanisms during hot deformation. Flow softening may indicate dynamic recrystallization $^{[13]}$, and oscillation curve may reveal cyclic dynamic recrystallization or localized flow ${ }^{[11,14]}$.

\subsection{Processing maps}

The deformation behavior of the materials was investigated through processing maps based on the principles of dynamic materials model (DMM) ${ }^{[15]}$. In this model, the deformed materials were considered as nonlinear power dissipation units $^{[16]}$. The power input in the deformed materials was dissipated at two parts during thermal deformation as follows: one part represents dissipated as heat through plastic deformation, represented by $G$, and the other part denotes microstructural changes, represented by $J$. The absorption power of materials during deformation can be derived as ${ }^{[17]}$ :

$$
P=\bar{\sigma} \dot{\bar{\varepsilon}}=\int_{0}^{\bar{\sigma}} \dot{\bar{\varepsilon}} \mathrm{d} \bar{\sigma}+\int_{0}^{\dot{\bar{\varepsilon}}} \bar{\sigma} \mathrm{d} \dot{\bar{\varepsilon}}=J+G
$$



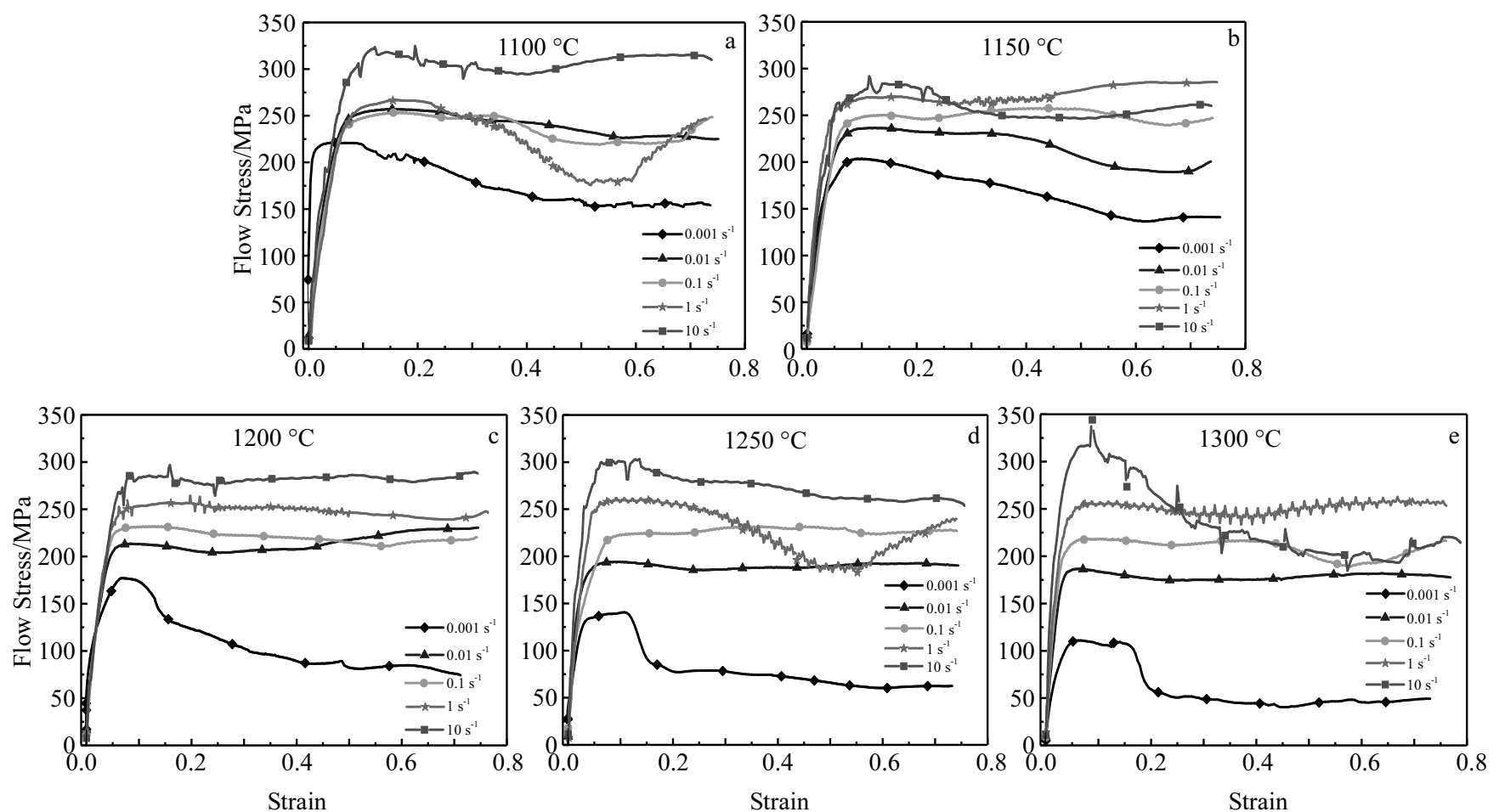

Fig.2 Stress-strain curves of Mo-Nb single crystals deformed at temperature of $1100{ }^{\circ} \mathrm{C}(\mathrm{a}), 1150{ }^{\circ} \mathrm{C}(\mathrm{b}), 1200{ }^{\circ} \mathrm{C}(\mathrm{c})$, $1250{ }^{\circ} \mathrm{C}(\mathrm{d})$ and $1300{ }^{\circ} \mathrm{C}(\mathrm{e})$ at various strain rates

where $\bar{\sigma}$ is equivalent stress $(\mathrm{MPa})$, and $\dot{\bar{\varepsilon}}$ is equivalent strain rate $\left(\mathrm{s}^{-1}\right)$. The power partitioning between $G$ and $J$ is given through the following equation:

$$
m=\frac{\mathrm{d} J}{\mathrm{~d} G}=\frac{\dot{\bar{\varepsilon}} \mathrm{d} \bar{\sigma}}{\bar{\sigma} \mathrm{d} \dot{\bar{\varepsilon}}}=\frac{\mathrm{d}(\lg \bar{\sigma})}{\mathrm{d}(\lg \dot{\bar{\varepsilon}})}
$$

The ratio is equivalent to the strain rate sensitivity index, $m$. Then, the power $J$ at a certain temperature with strain rate can be written as:

$$
J=\frac{m}{m+1} \sigma \dot{\varepsilon}
$$

where $\sigma$ is the flow stress $(\mathrm{MPa}), \dot{\varepsilon}$ is the strain rate $\left(\mathrm{s}^{-1}\right)$, and $m$ is the strain rate sensitivity index. The strain rate sensitivity $(m)$ of the flow stress determines the power that is partitioned between these two processes and this is unity for an ideal linear dissipater. The efficiency of power dissipation $\eta$ is obtained by comparing its power dissipation through the microstructural changes with that occurring in an ideal dissipater, and it is given by:

$$
\eta=\frac{\Delta J / \Delta P}{\left(\frac{\Delta J}{\Delta P}\right)_{\text {line }}}=\frac{m /(m+1)}{1 / 2}=\frac{2 m}{m+1}
$$

where $m$ is the strain rate sensitivity. The power dissipation map shows the variation of $\eta$ with $T$ and $\dot{\varepsilon}$, which characterizes of microstructural changes during deformation. The power dissipation map exhibits domains in which the efficiency shows a maximum local corresponding to each of the microstructural mechanisms. The condition for microstructural instability is obtained from the principles of maximum rate of entropy production as ${ }^{[18,19]}$ :

$$
\xi(\dot{\varepsilon})=\frac{\partial\left(\lg \frac{m}{m+1}\right)}{\partial(\lg \dot{\varepsilon})}+m<0
$$

where $\xi(\dot{\varepsilon})$ is called the dimensionless instability parameter, the variation of which with strain rate and temperature constitutes the instability map. The material falls into stable region when the value of $\eta$ is high and $\xi(\dot{\varepsilon})$ becomes positive. In the regions where the material undergoes instability of flow, the value of $\xi(\dot{\varepsilon})$ is negative ${ }^{[20,21]}$. Using the processing maps, the processes conditions can be optimized and expected microstructures can be obtained.

The processing map is consisted of power dissipation map and instability map, which exhibits the domains characteristic of different mechanisms, and the regimes described earlier for a large number of materials have been developed and compiled $^{[22,23]}$. The diagram of efficiency of power dissipation versus strain rate and deformation temperature is shown in Fig.3. Fig. 4 and Fig.5 show the power dissipation and flow instability of Mo-Nb single crystals deformed at strain 0.7 , respectively. The processing map is consistent with the power dissipation map and the flow instability map, as shown in Fig.6. It can be seen from Fig.4 that the peak efficiencies of 


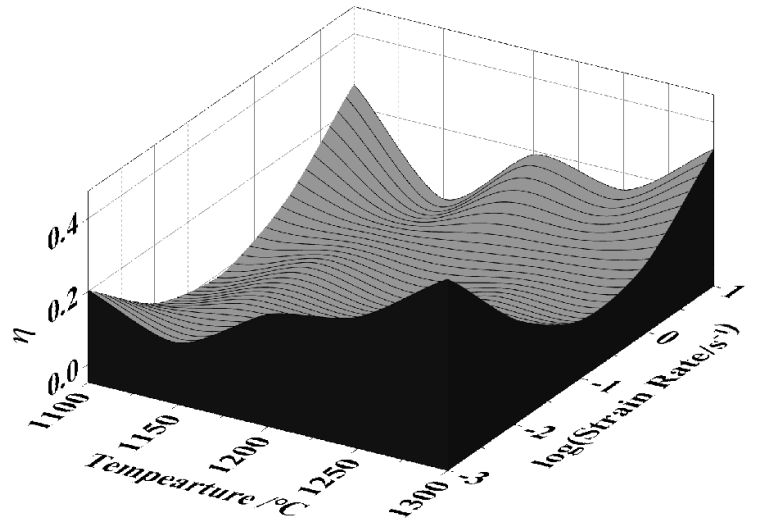

Fig.3 Diagram of efficiency of power dissipation vs strain rate and deformation temperature

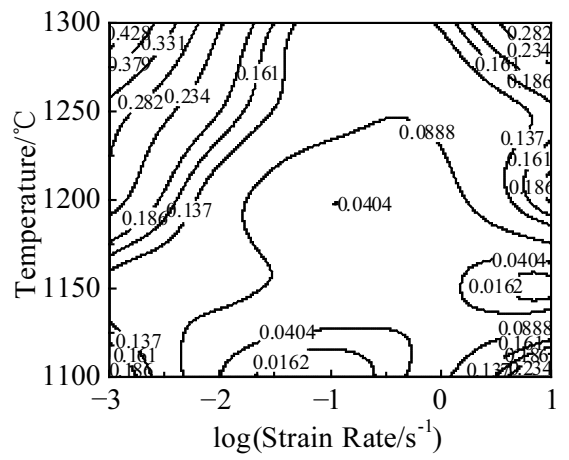

Fig.4 Power dissipation map of Mo-Nb single crystals at strain 0.7

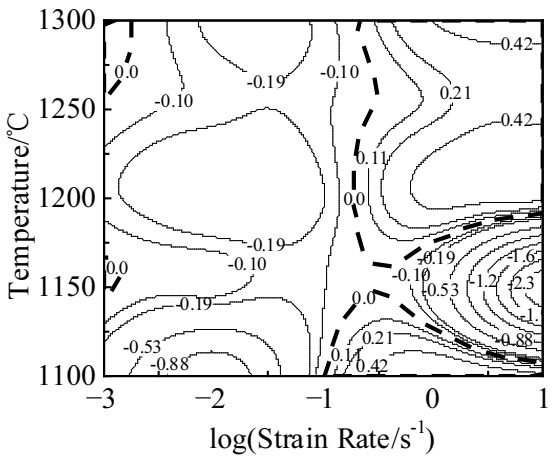

Fig.5 Instability map of Mo-Nb single crystals at strain 0.7

$43 \%, 38 \%$ and $28 \%$ in the deformation conditions of $1250{ }^{\circ} \mathrm{C} /$ $0.001 \mathrm{~s}^{-1}, 1300{ }^{\circ} \mathrm{C} / 0.001 \mathrm{~s}^{-1}$, and $1300{ }^{\circ} \mathrm{C} / 10 \mathrm{~s}^{-1}$, respectively. As demonstrated in Fig.6, the regions of the processing map can be divided into three sub-domains $(\mathrm{A}, \mathrm{B}, \mathrm{C})$ at the whole deformation temperature range $\left(1100 \sim 1300{ }^{\circ} \mathrm{C}\right)$, the first sub-domain is the deformation temperature range of 1100 $1300{ }^{\circ} \mathrm{C}$ and strain rate range of $0.001 \sim 0.1 \mathrm{~s}^{-1}(\mathrm{~A})$, the second sub-domain is the deformation temperature range of 1100

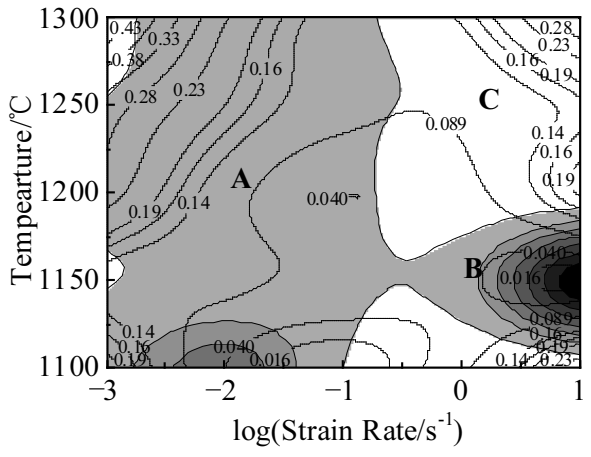

Fig.6 Processing map of Mo-Nb single crystals deformed 50\%

$1200{ }^{\circ} \mathrm{C}$ and strain rate range of $0.1 \sim 10 \mathrm{~s}^{-1}$ (B), while the last sub-domain is the deformation temperature range of $1200 \sim 1300{ }^{\circ} \mathrm{C}$ and strain rate range of $1 \sim 10 \mathrm{~s}^{-1}(\mathrm{C})$. The first two domains are instability domains, and the third one is the stability domain. There will be macro or micro structural defects when the Mo-Nb single crystals are deformed in the two plastic flow instability regions. Therefore, such combination of deformation temperature and strain rate should be avoided during the high temperature deformation of $\mathrm{Mo}-\mathrm{Nb}$ single crystals. As shown in Fig.6, there is a "safe" region in which the deformation temperatures range of $1190 \sim 1300{ }^{\circ} \mathrm{C}$ and strain rates range of 3.16 10 $\mathrm{s}^{-1}$ for the hot deformation of $\mathrm{Mo}-\mathrm{Nb}$ single crystals in the whole range of deformation temperature.

Therefore, the optimum conditions for hot deformation of $\mathrm{Mo-Nb}$ single crystals is the region of high temperatures $\left(>1190{ }^{\circ} \mathrm{C}\right)$ and strain rate $\left(>3.16 \mathrm{~s}^{-1}\right)$, which indicates that the material does not undergo instability of flow and could retain a single crystal structure after deformation. In addition, the power dissipation map suggests that the peak efficiency in "safe" region is $28 \%$ at $1300{ }^{\circ} \mathrm{C} / 10 \mathrm{~s}^{-1}$, which can be selected as an optimum thermal deformation condition, as a single crystal structure without defects may be observed from the metallography of the deformed specimens under this particular condition. Furthermore, limited by the parameters of the equipment, the maximum deformation temperature is $1300^{\circ} \mathrm{C}$, and the microstructure of $\mathrm{Mo}-\mathrm{Nb}$ single crystals may be improved at some different deformation conditions, which will be determined in the further researches.

\subsection{Microstructural analysis of Mo-Nb single crystals on the base of processing map}

According to the prediction results of the processing map, four typical samples corresponding to different domains were selected and cut along the compression axis to observe the microstructures. Fig.7a shows the microstructures of $\mathrm{Mo}-\mathrm{Nb}$ single crystals deformed at $1250{ }^{\circ} \mathrm{C} / 0.01 \mathrm{~s}^{-1}$ (sample $1 \#$ ) and $1150{ }^{\circ} \mathrm{C} / 10 \mathrm{~s}^{-1}$ (sample 2\#), which corresponds to the domain $\mathrm{A}$ and $\mathrm{B}$ in Fig.6, respectively. Fig.7b shows the microstructures of Mo-Nb single crystals deformed at $1100{ }^{\circ} \mathrm{C} / 0.01$ $\mathrm{s}^{-1}$ and $1300{ }^{\circ} \mathrm{C} / 10 \mathrm{~s}^{-1}$, which corresponds to the domain $\mathrm{A}$ and 


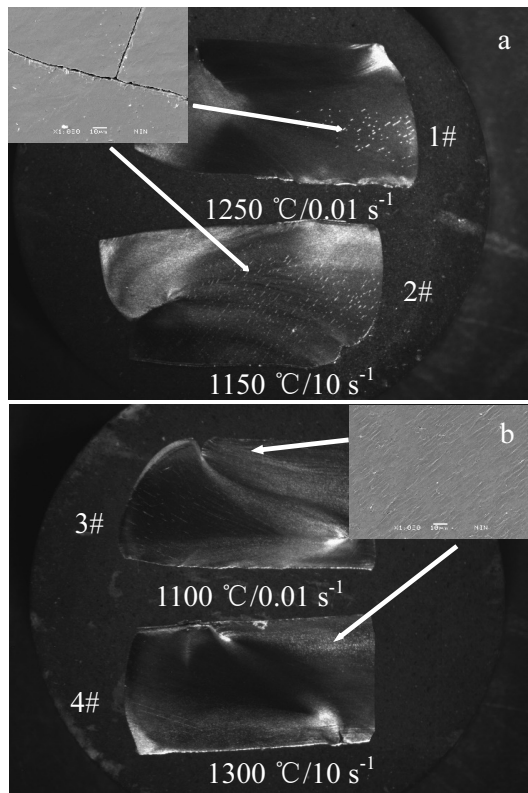

Fig.7 Microstructures of $\mathrm{Mo}-\mathrm{Nb}$ single crystals deformed at different conditions: (a) $1250{ }^{\circ} \mathrm{C} / 0.01 \mathrm{~s}^{-1}$ and $1150{ }^{\circ} \mathrm{C} / 10 \mathrm{~s}^{-1}$, and (b) $1100{ }^{\circ} \mathrm{C} / 0.01 \mathrm{~s}^{-1}$ and $1300{ }^{\circ} \mathrm{C} / 10 \mathrm{~s}^{-1}$

$\mathrm{C}$ in Fig.6, respectively. As shown in Fig.7 and Fig.8, lots of orthogonal cracks, which result from the movement of dislocations along with the glide planes, are observed in sample $2 \#$ and $3 \#$. For sample 1\#, less cracks can be observed only in parts of the sample and few cracks are found in sample 4\#. As can be seen from the rocking curve of sample 4\# shown in Fig.9, the deformed sample still retains a single crystal structure. It means that the sample deformed at 1300 ${ }^{\circ} \mathrm{C} / 10 \mathrm{~s}^{-1}$ does not undergo instability of flow, and macro or micro structural defects (such as cracks or recrystallization) are not found in the deformed sample. From microstructural analysis of the deformed samples and the principles of processing maps, the deformation conditions at the region of

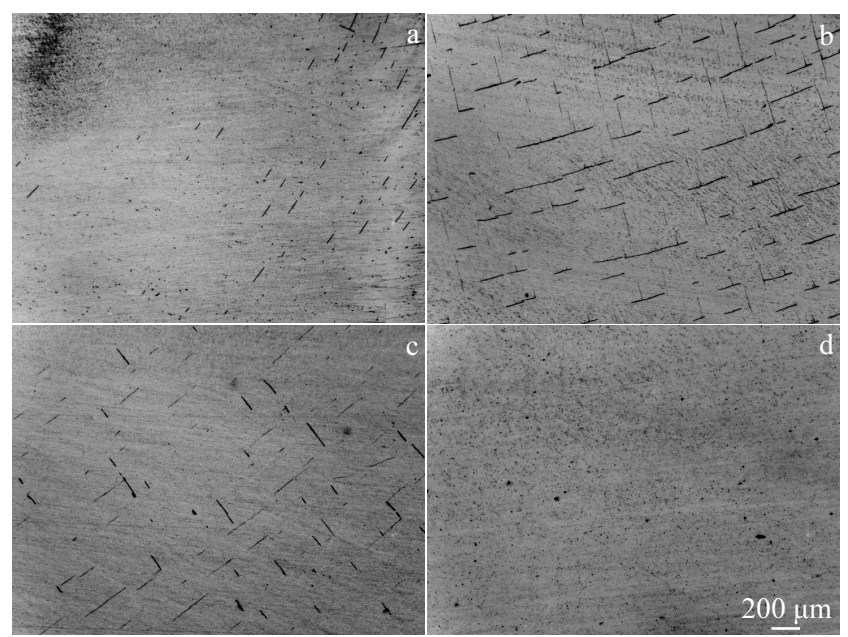

Fig.8 Microstructures of samples 1\# (a), 2\# (b), 3\# (c), and 4\# (d)

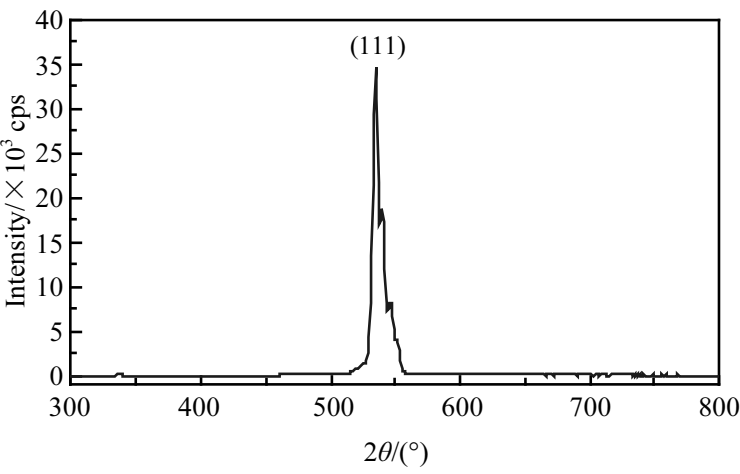

Fig.9 Rocking curve of sample $4 \#$ deformed at $1300{ }^{\circ} \mathrm{C} / 10 \mathrm{~s}^{-1}$

high temperature $\left(>1190{ }^{\circ} \mathrm{C}\right)$ and high strain rate $\left(>3.16 \mathrm{~s}^{-1}\right)$ can be chosen in the process of deformation, and deformation conditions at instability region should be avoided. In addition, it is worthy noting that near the large deformation area of all the deformed samples, oriented fibrous tissue can be observed, because the number of slip lines increases fast during deformation and the single crystals tissue is decomposed into some misorientation regions by slip bands. These misorientation regioning are constantly shifting in the process of deformation, resulting in oriented fibrous tissue ${ }^{[12]}$.

\section{Conclusions}

1) The flow stress during the hot deformation of Mo-Nb single crystals is affected significantly by the deformation temperature and strain rate. The flow stress decreases with increasing of the deformation temperature, and increases with increasing of the strain rate.

2) The optimum conditions for thermal deformation of $\mathrm{Mo}-\mathrm{Nb}$ single crystals is in the region of high temperature $\left(>1190^{\circ} \mathrm{C}\right)$ and high strain rate $\left(>3.16 \mathrm{~s}^{-1}\right)$.

3) Lots of orthogonal cracks are observed in specimens deformed at lower temperature $\left(<1200^{\circ} \mathrm{C}\right)$. Less or few cracks can be observed in samples deformed at higher temperature $\left(>1250^{\circ} \mathrm{C}\right)$.

4) The specimen deformed at $1300{ }^{\circ} \mathrm{C} / 10 \mathrm{~s}^{-1}$ still retains a single crystal structure. It does not undergo instability of flow and can be chosen as optimal deformaion condition, which are in good agreement with the prediction from processing map.

\section{References}

1 Malehev M B. Translated by Li M S. Vacuum Metallurgy of Refractory Metals and Hard Materials[M]. Beijing: The Metallurgical Industry Press, 1986: 179 (in Chinese)

2 Glebovsky V. Recrystallization[M]. Rijeka: InTech, 2012: 59

3 El-Gebk M S, Hoover M D. Proceedings of 10th Symposium on Space Nuclear Power and Propulsion[C]. New York: American Institute of Physics Press, 1993: 267

4 Zee R H, Xiao Z, Chin B A et al. Journals of Materials Processing Technology[J], 2001, 113: 75 
5 Savitsky E M. Single Crystal Refractory Metals, Alloys and Compounds[C]. Moscow: Nauka Press, 1984: 196

6 Liu J, Zee R H. Proceedings of the $2^{\text {nd }}$ pacific Rim International Conference on Advanced Materials and Processing[C]. College Park: American Institute of Physics, 1995: 383

7 Zheng Xin, Bai Run, Wang Donghui et al. Rare Metal Materials and Engineering [J], 2011, 40(10): 1871 (in Chinese)

8 Liu J, Zee R H, Chin B A. Journals of Materials Processing Technology [J], 1999, 89: 425

$9 \mathrm{Hu}$ Zhongwu, Li Zhongkui, Zhang Qing et al. Rare Metal Materials and Engineering [J], 2007, 36(12): 2255 (in Chinese)

$10 \mathrm{Hu}$ Zhongwu, Li Zhongkui, Zhang Qing et al. Nonferrous Metals[J], 2008, 60(2): 1 (in Chinese)

11 Zhu Y C, Zeng W D, Feng F et al. Materials Science and Engineering $A[\mathrm{~J}], 2011,528: 1757$

12 Lyakishev N P, Burkhanov G S. Metallic Single Crystals[M]. Moscow: Eliz, 2002: 165

13 Li A B, Huang L J, Meng Q Y et al. Mater Des[J], 2009, 30: 1625

14 Zeng Weidong, Zhou Yigang, Shu Ying et al. Rare Metal
Materials and Engineering[J], 2007, 36(1): 1 (in Chinese)

15 Prasad Y V R K, Seshacharyulu T. International Materials Reviews[J], 1998, 43(6): 243

16 Kong Y H, Chang P P, Li Q et al. Journal of Alloys and Compounds[J], 2015, 622: 738

17 Gegel H L, Malas J C, Doraivelu S M. Innovations in Materials Processing[M]. New York: Plenum Press, 1985: 137

18 Radhakrishna B V, Mahajan Y R, Roshan H M. Metallurgical and Materials Transactions A[J], 1992, 23: 2223

19 Ziegler H. Progress in Solid Mechanics[M]. New York: Wiley Press, 1963: 91

20 Tan Y B, Yang L H, Tain C et al. Materials Science and Engineering $A[\mathrm{~J}], 2014,597: 171$

21 Zhang T, Rao K P, Prasad Y V R K et al. Materials Science and Engineering $A[\mathrm{~J}], 2013$, 559: 773

22 Prasad Y V R K, Rao K P, Sasidhara S. Hot Working Guide: A Compendium of Processing Maps[M]. Russell: ASM International, 2015: 195

23 Prasad Y V R K, Sasidhara S. Advanced Materials \& Processes[J], 1997, 151(4): 45

\title{
Mo-Nb 单晶材料的加工图及热变形行为
}

\author{
张 文 $^{1,2}$, 高选乔 ${ }^{2}$, 程 军 $^{2}$, 胡忠武 ${ }^{2}$, 李来平 ${ }^{2}$, 赵 涁 $^{1,2}$, 张平祥 ${ }^{1,2}$ \\ (1. 西北工业大学, 陕西 西安 710072) \\ (2. 西北有色金属研究院，陕西 西安 710016)
}

\begin{abstract}
摘 要: 运用 Prasad 失稳准则建立了 $\mathrm{Mo}-\mathrm{Nb}$ 单晶材料的加工图, 研究了材料在 $1100 \sim 1300{ }^{\circ} \mathrm{C}$, 应变速率 $0.001 \sim 10 \mathrm{~s}^{-1}$ 范围内的热变形特 征。结果显示, 变形温度和应变速率对 Mo-Nb 单晶材料的流变应力有着显著的影响。材料的加工图表明, Mo- $\mathrm{Nb}$ 单晶的最佳热变形条 件为变形温度 $>1190{ }^{\circ} \mathrm{C}$ 和应变速率>3.16 s ${ }^{-1}$ 。材料的显微组织表明, 在 $1150{ }^{\circ} \mathrm{C} / 10 \mathrm{~s}^{-1}$ 和 $1100{ }^{\circ} \mathrm{C} / 0.01 \mathrm{~s}^{-1}$ 变形条件下变形后的样品内部 出现了大量的裂纹, 且裂纹区域面积较大; 经 $1250{ }^{\circ} \mathrm{C} / 0.01 \mathrm{~s}^{-1}$ 变形的样品 内部只有局部位置出现少量裂纹; $1300{ }^{\circ} \mathrm{C} / 10 \mathrm{~s}^{-1}$ 变形的样品 内部未发现明显的裂纹。X 射线衍射结果显示, 经 $1300{ }^{\circ} \mathrm{C} / 10 \mathrm{~s}^{-1}$ 变形后的样品仍保持相对较好的单晶组织。表明在 $1300{ }^{\circ} \mathrm{C} / 10 \mathrm{~s}^{-1}$ 变形 条件下, 样品在变形过程中没有发生变形失稳, 这与采用加工图预测的结果相符。
\end{abstract}

关键词: $\mathrm{Mo}-\mathrm{Nb}$ 单晶材料; 加工图; 热模拟压缩

作者简介: 张 文, 男, 1981 年生, 博士生, 高级工程师, 西北工业大学, 陕西 西安 710072, 电话: 029-86231082, E-mail: gwenzh@163.com 